\title{
The Local Wisdom of Kidung Sri Bedhaya: The Ruler's Hegemony Towards a Woman
}

\author{
Hartikaningsih'*, Andayani², P A W Wibowo ${ }^{3}$ \\ 1,2,3 Sebelas Maret University, Indonesia \\ E-mail: ningsihartika@gmail.com
}

\begin{abstract}
Monologue drama performance with Javanese as its language is seemingly rare to find. Kidung Sri Bedhaya monologue drama created by Trisno Santoso applies feminism to be the approach. It is as considered by litterateurs that woman is as an attractive topic to discuss. This research belongs to descriptive qualitative with document study without any places taken Moreover, in this research, the data are in the form of written descriptive. A woman, in this case, tends to be left behind as she is placed under man in term of position and domination while in fact, rulers are not allowed to be arbitrary towards their families, slaves, and those who work under the governmental. This is in contrast to what was occurred that authority as if blinds the boundary between personal and government affairs. Finally, through Kidung Sri Bedhaya, ruler's hegemony towards woman is able to investigate.
\end{abstract}

Keywords: Local Wisdom; Kidung Sri Bedhaya, Hegemony; Feminism

\section{INTRODUCTION}

Javanese literature contains complex and relevant values dealing with any problems emerge in society, mainly Javanese [1]. There are particular aims proposed by litterateurs while creating such works of literature. Hence, to them, works of literature are a tool of self- expression while in common, they are enjoyed, and conceived. To some extends, they gain benefit, are being exampled, and applied in daily life. Thus, works of literature are a tool of entertaining their readers, listeners, as well as audiences.

According to Tankersley, by reading a literature work, the writer's particular intention is able to catch as readers' lower order thinking skills are applied. Moreover, to develop higher order thinking skills, appreciation and interpretation are needed [2].

It is stated that the use of Javanese language is influenced by two factors: both from the speaker and listener [3]. Kidung Sri Bedhaya, moreover, can be considered as one of the tools to maintain the existence of Javanese language that is in contrast with the condition in reality about the less enthusiasm from the society towards their mother tongue.

Kidung Sri Bedhaya is a monologue drama. The monologue is considered interesting in a literature field. Its way of conveying is able to attract both audiences and researchers to do the investigation. The intrinsic and extrinsic element in the monologue is explained. The values contained in it are able to give the life lessons. These values have a role to develop human's attitude, personality, and customs according to the existing norm from the society.

The approach in this research belongs to feminism. This kind of approach focuses on the struggle for woman's rights that refuse everything subordinated, demeaned, and marginalized by dominant cultures in both economic, social, and political fields. Woman's weaknesses are founded through this literature work, to be mentioned as oppression towards them, gender problem, and sexuality matter.

Discussing feminism means to have a concern about a woman. As they are part of society, everything done by them will always be related to social-cultural context. Thus, each activity they have will always be related to 
those who come around. Women with particular uniqueness on themselves are able to be a never-ending inspiration. They are able to attract men. Although on the other side, women are considered as weak and should be sent down to men. Hence, these side of women influences men with a bad attitude to do the exploitation of how an attractive woman is. There is even an assumption that women are despicable, a second-class human who although are beautiful, but their existence is none to be recognized. One of Aristotle's philosophers, Thomas Aquinas states that women are imperfect men [4].

Mostly, people do not pay attention to appalling cases occurred to women in their daily life. Consciously or not, they are considered to be in a weak target of their condition. The idea of considering women as weak is viewed as negative as it belongs to pessimistic. In fact, both news and literature work state that woman is susceptible and tends to be a target of violence and terror [5].

A woman is a very interesting character to be discussed by the litterateurs. Her existence is in between two poles of tradition and the polarity of modernization thus poses a challenging problem to be investigated. On the one hand, women must submit to and be bound by tradition, on the other one, she has already stepped in the world of modernization that offers freedom. The condition, hence, is that her personal integrity shackled all the rules of tradition. Instead, the consciousness of the personality opens her mind to become a person who freely actualizes herself out of the bondage [6].

Fakih posits that feminism is based on a premise stating that woman is basically oppressed and exploited. It is as a struggle in order to transform a previously unfair system toward a previously unfair system toward a more equitable system for both genders. Feminism, moreover, is a social transformational movement. Its aim is to create a new order which is better and fairer to both man and woman [1].

'Wanita' and 'Perempuan' are two words referring to the same human gender (woman), means to have an ability to be with child and breastfeed or in other words namely as 'female'. Basically, these two words contain different sense inside. A previous definition refers to 'Perempuan', as 'Perempuan' is a creature that physically has breasts, has female genital organs, and has an ability to be with child, give birth, and breastfeed [7].

According to their existence, 'Perempuan' has a strong sense than 'Wanita'. 'Perempuan' is defined as physically and mentally to be a 'Perempuan'. 'Wanita', hence, is more on a matter of human's instinctive. Terms 'female instinct' is different to 'feminine instinct'. A term 'she-male', moreover, refers to a female instinct that a man can also have [7]. Therefore, this research is more on the use of 'Perempuan' instead of 'Wanita'. Problems about a woman are strongly contained in Kidung Sri Bedhaya performance created by Trisno Santoso.

Trisno Santoso is one of the famous drama writers in Surakarta. Aside from becoming a lecturer of Teater and Pedhalangan (Theater and Puppetry) in Indonesian Institute of Arts, he is an active practitioner from the theater field, both as an actor and director. Hence, he is known for his literary works of ketoprak scripts, and else. As time goes by, Trisno Santoso who is also recognized as Pelok is productive and active in writing ketoprak script.

Out of many scripts created by Trisno Santoso, one of them will be used as an object to be investigated through this research. This refers to Kidung Sri Bedhaya, a Javanese monologue performance which was performed through Javanese monologue competition taking place in Yogyakarta at the year of 2013. This performance resulted in the best champ winning. Kidung Sri Bedhaya itself tells about a woman with many grief stories in her life. Sri Ngabekti, the main character of this monologue drama, is a victim of the authority of a ruling king at that time. She is trapped in a condition that she should follow the command of her ruler to fulfill his desire. Time flies and after what had been occurred to Sri Ngabekti, it is known that she is pregnant. Out of the expectation, the ruler, Sinuwun, is extremely mad and asks Sri Ngabekti to do the abortion since he does not want to have a child with his servant.

Trisno Santoso is a writer and director with many achievements in the art field. Some of them are: (1) best director in Central Java in 1989, (2) best director of Javanese competition in Senior High Schools of Central Java in 2002, (3) best writer of Javanese drama competition in Senior High Schools of Central Java in 2002, (4) best director of ketoprak festival of Central Java in 2004, (5) fourth champ of Javanese script writing of Central Java in 2004, and (6) parallel champ of Javanese drama festival in Senior High School grade in 2014.

Based on the observations conducted by the researcher, there has been none about Kidung Sri Bedhaya as a research object. Hence, the researcher is interested to conduct research with monologue drama script of Kidung Sri Bedhaya as its object and feminism to be the approach. In this script, a female is placed under the position of men who have authority. A description of the main character of this script is as the main reason of the researcher 
for using this script to be the object with feminism as the approach while comparing to other Trisno Santoso's works.

\section{METHODOLOGY}

This research belongs to descriptive qualitative with document study without any places taken. Qualitative method is one kind of research procedure having descriptive data in the form of written or spoken words resulted from the observed people and event [8]. As a part of qualitative research, hegemony approach owns the researcher to be the instrument of his or her research. A researcher determines the focus of his or her research, chooses the informant/s, collects the data, does the assessment and analysis, interprets the data, and makes the conclusion based on what had been found [9]. Moreover, in this research, the data are in the form of written descriptive.

The methodological premises are based on the qualitative approach, as it considers the necessity of a group of interpretative techniques to express the sense of social phenomena and the comprehension of the meanings of human actions and relations [10].

\section{RESULT AND DISCUSSION}

Hegemony is derived from a word Hegisthai (Greek) that has a meaning as lead, leadership, an authority that exceeds its another one [11]. Gramsci has an initial concept on hegemony which is described as a class that masters other classes below by violence and persuasion [12]. Moreover, hegemony is defined by Gramsci as an organization consensus contained moral and intellectual leadership. To make it stable towards the ideology, moral, and intellectual, authority is used as the instrument.

Moral and intellectual leadership, as well as political domination, are conducted in the form of control led by those who dominate the two leaderships. Hence, there are two ways of ruler while conducting an authority towards its classes, such as violence and persuasion. Those considered as dominant will be right, and vice versa. Therefore, the ruler's hegemony towards woman contained in Kidung Sri Bedhaya by Trisno Santoso is explained:

\subsection{Tend to Curse His Servant}

Kanjeng is the highest place to a structure of government in a palace. Hence, she/he has a right on leading and regulating his/her area. It is in contrast to a fact that sometimes, appropriateness occurs to the given right/s. The detail will be written through the below conversation:

Kanjeng easily says 'deaf' to his/her servant (Sri) as she does not hear it when Kanjeng calls her. A swearing word ' $a s u$ ' is roughly expressed by Kanjeng to Sri as she does not carefully listen to the command. Kanjeng asks Sri to listen, follow, and hurry for the command given to her without caring for many reasons. This reflects a must from a servant to respect his/her ruler.

\subsection{Give Threat to Abdi}

Kanjeng Menggung conveys a guideline regarding what should be done by Sri inside the Keraton. She, moreover, explains to the responsibilities that should be followed by her servant. At the end of the dialogue, however, Kanjeng gives threat to Sri that if she does not do her responsibilities, she will be chased from the Keraton away. Sri, who is an adolescent, has given a threat of dealing with her responsibilities. Yet, Kanjeng Menggung does not care about it that she should work as if she was an adult.

\subsection{Command of Fulfilling A Personal Affair}

Someone who places nation and state's concern over the personal one considers having a nationalism .Kidung Sri Bedhaya, then, tells about a ruler that seems to do the opposite. One can be seen from Sinuwun that gives a command to Sri to go to Jakarta. It is informed that there will be a performance of Bedhaya Anglir Mendhung in one of the famous hotels in the city. Hence, Sri is asked by Sinuwun to go there early. It is not a big deal to Sri as she will be given a free cost to go to the city. When it is the time, Sri goes to Jakarta to sing (in Javanese) in Bedhaya Anglir Mendhung as informed by Sinuwun a month ago. Based on what was commanded, she goes to Jakarta alone. The servants of the palace serve Sri well before her departure. They hand over Sri's luggage, pick 
her up in the airport in Jakarta, accompany and allow her to go to room 125 in a hotel. It is proven through the conversation:

Sri is extremely shocked. Why does Sinuwun sit in the room she originally belongs to? After that, it is known that he is there to listen to Sri's singing voice and take a look at her dance.

Hence, Sri's thoughts prove wrong. She basically thought that Bedhaya Anglir Mendhung performance will be presented and watched in front of a lot of people. Therefore, it is contrary to what she gets that she has to present it privately in room 125 with Sinuwun as the only audience.

Susan Brownmillershares argues that men use oppression as a strategy to maintain their patriarchy. Women, moreover, is considered as a single class with the same experience of oppression. One of them is rape. All of the women as the rape victims are treated that it leads to those who are in the society of patriarchy. This is a way of dominating women in patriarchy as it brings men the benefit [13].

As a servant, it is impossible for Sri to not accept what was commanded by her ruler. Slightly, Sinuwun wants to be intimately served by his female servant. As a servant, there is no choice aside of following him, although she loses her pride.

From the order conversation analyzed before, it can be summed up that Sinuwun does not do his right as a leader and ruler in a region as well as governmental appropriately. Sinuwun, hence, makes an 'illegal' relationship with her servant. To fulfill its personal affair, Sinuwun is subtly lying.

\subsection{Make Fun of Woman}

Ideally, a leader should be a good example for his/her servant. It is in contrast to what was written through as story contained in this literature work that leader in this context cannot be good towards his/her servant.

Sinuwun is enthusiastically curious about his female servant's maturity. He clearly asks it to Sri. It is stated in the word 'bulanan' from the conversation above that has the meaning of a woman's period.

Without any thoughts, Sri answers 'I have not'. She has not been understood the meaning of 'bulanan' as intended by Sinuwun. Sri, then, becomes his target. Sri was asked to fulfill Sinuwun's desire several times. One day, Sri is pregnant with Sinuwun's child. He is aware of this news but getting mad with it. Sinuwun does not have a willing to be a father of his biological child. Sri is shocked and disappointed in the decision made by him.

Sinuwun had been made fun of Sri, his servant. He illegally built a forbidding relationship with her. This case, moreover, is in line to the research conducted by Kavya about a struggle of the oppressed woman. The concerns were about to rape and marriage. Hence, the similarity to this research was placed on feminism. In Kavya's research, woman's existence against the injustice of gender is written that it relates to this research. Yet, the real manifestation of the struggle of female characters is not described in detail [14].

\section{CONCLUSION}

Rulers have authority upon governmental in such areas. Hence, the responsibilities should be occupied that it is a prohibition for them to do the arbitrary towards their citizen. Their attitudes and speech should be well managed as they stand to be an example for their citizen. Each good deed will be imitated by them and vice versa. The result of this research shows that Sinuwun as one of the rulers in a kingdom is considered as wrong during towards his authority.

\section{REFERENCES}

[1] A. Rokhmansyah, Studi dan Pengkajian Sastra: Perkenalan Awal Terhadap Ilmu Sastra. Yogyakarta: Graha Ilmu, 2014.

[2] S. M. L. A. Fajarini, "The Swings of Selendang: a Deconstruction Point of View of Tohari’s Ronggeng Dukuh Paruk (The Dancer)," J. Lang. Lit., vol. 17, no. 1, pp. 161-166, Oct. 2017.

[3] K. Saddhono, Etnik Madura; Perspektif Integrasi Linguistis Kultural. Surakarta: Pustaka Cakra, 2004.

[4] Sugihastuti and Suharto, Kritik Sastra Feminis: Teori dan Aplikasinya. Yogyakarta: Pustaka Pelajar, 2002.

[5] L. H. L. Ruruk and N. L. P. Rosiandani, "The Resistance of Women towards Sexual Terrorism in Eve 
Ensler's," Vagina Monologues J. Lang. Lit., vol. 15, no. 1, pp. 46-56, 2015.

[6] S. I.N., Analisis Sastra: Teori dan Aplikasi. Yogyakarta: Ombak, 2014.

[7] N. D. Safitri and N. Maghfirah Aesthetika, "Makna Khitan Perempuan dalam Film Pertaruhansegmen 'Untuk Apa,"” KANAL J. Ilmu Komun., vol. 2, no. 2, p. 169, Oct. 2016.

[8] J. Moleong, Metodologi Penelitian Kualitatif. Bandung: Remaja Rosdakarya, 2014.

[9] Sugiyono, Metode Penelitian Kuantitatif, Kualitatif dan R\&D. Bandung: Alfabeta, 2009.

[10] A. Dias, D. A. De Oliveira, M. H. S. Cruz, and S. S. Amorim, "Body, Gender, and Sexualities Approaches in the Political-Pedagogical Project in a High School in Brazil," Int. Educ. Stud., vol. 10, no. 6, p. 1, May 2017.

[11] R. N.K, Teori, Metode, dan Teknik Penelitian Sastra dari Strukturalisme hingga Poststrukturalisme Perspektif Wacana Naratif. Yogyakarta: Pustaka Pelajar, 2004.

[12] V. L. Roger, "Trends in Heart Failure Incidence and Survival in a Community-Based Population," Jama, vol. 292, no. 3, p. 344, Jul. 2004.

[13] L. S. Budi and D. Widyastuti, "Self-Determination to Fight Oppressions as Seen in the Main Character of the Color Purple by Alice Walker," J. Lang. Lit., vol. 17, no. 2, pp. 116-124, Oct. 2017.

[14] B. Kavya, "Marial Rape in Shashi Deshpande's Fiction," Indian Streams Res. J., vol. 2, no. 4, 2012. 